Mini Review

\title{
Building Ethical Climate in a Foreign Country: A Dilemma for the Foreign Multinationals
}

\section{Dimple Grover}

Educational Consultant, India

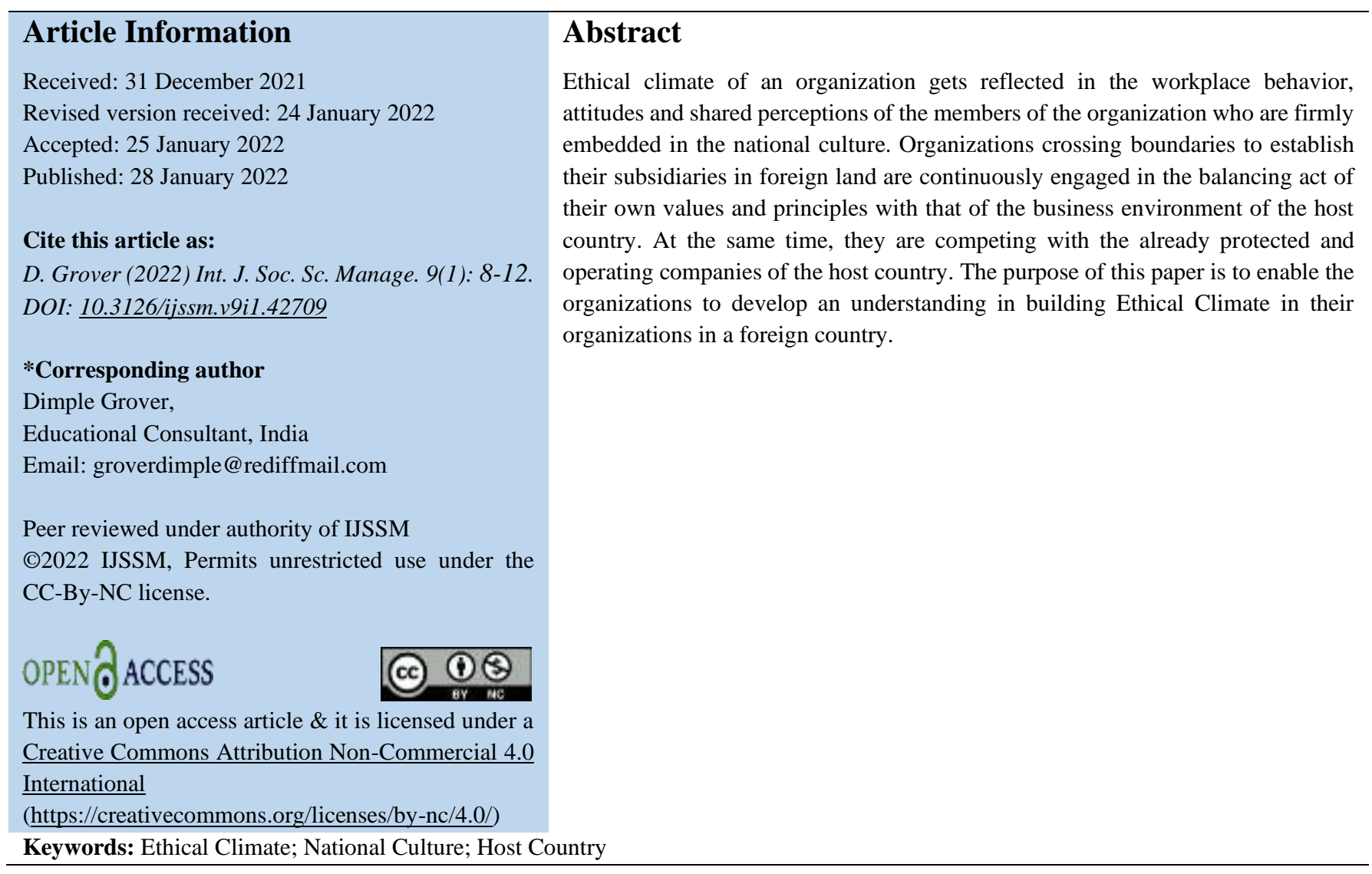

\section{Introduction}

Ethical Climate (EC) of an organization represents the DNA of that organization. Having its theoretical underpinning in sociology and moral science, EC ascertains an employee's decision while facing ethical dilemma. The decisions undertaken project the key philosophy governing the organization. Ethical work climate, thus, represents a set of shared formal and informal perceptions of procedures and policies, which shape expectations for ethical behavior (Victor \& Cullen, 1988).
With the increase in number of legal and fraudulent cases, EC has been drawing attention, as its impact on individuals and organizations can be subsequently felt. (Newman et al., 2017). The concern related to Ethical Climate increases multifold as organizations transcend the boundaries. An understanding of the values, sociocultural norms, political will and governance practices would enable the organizations to adapt and adjust their operations to develop ethical culture. Thus, Multinational companies (henceforth MNCs) with world-wide subsidiaries need to recognize the 
impact of socio-cultural values on local organizational behavior to be able to successfully transfer the know-how to various local units (Arora, 2005).

Referring to EC as an implicit indicator in the context of decision making within the organizations, (Olson, 1998), pointed that "EC provides the context in which ethical behavior and decision making occurs."

Though, the studies on National Culture and Ethical Climate are negligible, yet there has been concrete evidence of strong correlation between National culture and Organizational Culture. The paper attempts to establish linkages between national culture, organizational culture and ethical climate. Organizational culture acts as a mediator between national culture and ethical climate of the organizations.

\section{Effect of National Culture on Organizational Culture}

Hofstede (2001), Nelson and Gopalan (2003), and Nazariana et al. (2017) in their studies have pointed out the effect of national culture on organizational culture. Cultural norms, values and beliefs are forced on organizations through societal establishment (Dennis et al., 2007; Fitzsimmons \& Stamper, 2014; Gerhart, 2009; Hofstede, Hofstede, \& Minkov, 2010). Culture, though, not directly visible and observable can be inferred from the values and artifacts, thus, the basic assumptions are adopted by the majority of organizational members (Hofstede, 1980; Sathe, 1985; Schein, 1999). The culture of a country acts as a glue to its nationalities as they not only share the values but also "construe knowledge and produce social behavior" (Scherer et al., 2006)

Organizations are deeply embedded into a national or a society's culture. Deal and Kennedy (1982) maintained that organizational culture is made of values, nevertheless they are as well included in their description of the business environment, heroes, rites, rituals and, cultural links. Mead and Andrews (2009) observed that, the understanding of 'organizational culture' is difficult as the word did not have any single conventional meaning. Many different definitions have existed over time which may consist of organizational structure and rules, values, feelings, norms as well as the organizational climate. Further, a review of literature indicates that the concepts of climate and culture have been widely accepted as a means to explain organizational behavior generally and ethical behavior specifically (Moran and Volkwein, 1992; Olson, 1998; Trevino, 1990).

Thus, organizational culture encompasses the ethical climate. Ethical Climates develop as a result of organizational policies, practices, and leadership, and exert significant influence on the ethical decision making of organizational members and their subsequent attitudes and behavior at work (Schminke et al., 2007; Simha \& Cullen, 2012).

\section{Correlation Between National Culture and The Organizational Culture}

A number of studies have established the correlation between national culture and organizational culture. Various researches Minkov and Hofstede (2012), Klimas (2016) pointed towards understanding the culture of people from different geographical environment. One of the key issues, often faced by the MNC's is the influence generated by the society on managing the friction in employeeorganization, Fitzsimmons \& Stamper, (2014). MNC's not only have to be wary of the host country's national culture in building the organizational culture but also have to be cautious about the elements of one's own cultural milieu and communicate it effectively. Taylor and Osland (2012) point out that the limited success of MNCs in transferring knowledge and paucity of research on global organizational learning can be attributed to intercultural communication. Intercultural communication is defined as, 'symbolic process in which people from different cultures create shared meaning' (Lustig and Koester, 1999). In an interesting study, Yeong-Hyun Kim \& Short JR (2008), pointed out the differences emerging in Korean and Indian managers specifically in terms of each nationality having distinct idea regarding each other's practices in the management of dealers, suppliers and consumers. Due to lack of understanding, intercontinental businesses are often confronted with collapse and difficulties which are attributed to insufficient indulgent of the cultural circumstances other than market conditions (Adler, 1991; Lu et al., 2016).

The organizations, thus, have a task to maintain a balance between establishing their own culture and the culture of the destination country. Also, the individuals working in an organization exhibit inherent characteristic of being embedded in the culture of the society or place where they come from. There has been evidence that the people working in these organizations are firmly entrenched in their own cultural institutions and have their own norms and characteristics leading to the decision making and ethical climate of the organization.

\section{Ethical Climates Help in Understanding the Ethical Behavior}

"Ethical climates are conceptualized as general and pervasive characteristics of organizations; affecting a broad range of decisions" (Victor \& Cullen, 1988, p.101). The Ethical Climate Questionnaire is "simply an instrument to tap, through the perceptions of organizational participants, the ethical dimensions of organizational culture" (Victor \& Cullen, 1988, p.103). EC can be implored by understanding how the employees of an organization engage in the day-today tasks. EC helps in establishing the process of 
standardization by laying down the rules and procedures as it emerges from organizational processes transmitting managerial expectations in terms of moral behaviors and processes for ethical problems (Mayer \& et al., 2014) and exerts a decisive influence over attitudes and behaviors of members in the organization (Peterson, 2002; Cullen etal., 2003; Tsai and Huang, 2008; Leung, 2008; Mulki et.al., 2006 Goldman \&Tabak, 2010; DeConinck, 2011; Unal, 2012). Thus, EC helps in understanding ethical behavior of individuals as well the impact of situational and organizational context in understanding individual ethical conduct (Lewin, 1951). "Ethical climate frames the work attitudes, workplace behavior, psychological states of the employees, influencing performance outcomes at individual, group and organizational level Newman et.al. (2017)." Representing a strong group regulation tool (Ellemers et al., 2013), ethical climate becomes central to organizational life as a way to show the core values of the company both internally and externally, to promote identification and commitment with the organization, and to manage deviance (Ceschi et al., 2016). EC influences the individual and organizational outcomes and behaviors (Newman et al., 2017).

Researches on EC have mostly focused on understanding the variance between climate types or in terms of establishing its relationship specifically when comparing ethical climates that promote prosocial behavior with those suggesting more individualistic behavior, it emerges that the former are more strongly associated with work performance and employees' positive attitudes and behaviors (Peterson, 2002; Briggs et al., 2012; Ehrhart and Raver, 2014; Mayer, 2014; Pagliaro et al., 2018).

Thus, it seems crucial for organizations to understand the positive and negative consequences of different kinds of ethical climates in order (a) to avoid the associated financial and sociopsychological costs and (b) to rely on those climates that, on the contrary, may increase employees' positive relationship with the organization and positive behaviors. Murphy (1981) suggested that an “organization's ethical climate may also have an impact on the ethical behavior of individual members." The impact of sociocultural influences quite often crosses the boundaries and have an effect on all the domains including organizational workforce

\section{Role of National Culture, Organizational Culture and Ethical Climate}

An understanding of the national culture will help multinational companies to bridge the cultural gap across the countries. National culture is a collective programming of the mind which distinguishes one group from another (Hofstede 2001). Broadly we assume that national cultures produce patterned ways of thinking (Kluckhohn, 1954) as a set of shared meaning systems (Shweder et al., 1984) that is transmitted from one generation to another through the process of observation and modeling. Studies have shown that, despite their heterogeneity within a country, organizational cultures are affected by national cultures (Soeters and Schreuder, 1988; Hofstede et al., 1991.

The characteristics of an organization are a reflection of the society around it. The employees working in the organization are deeply ingrained in the value and cultural norms of the society. According to Nikčević (2014), "every organization possesses its own culture, that mainly subjective to the national culture of the society in which it was formed. As national culture regulates values of organizational culture of organisations/companies operating within its context, and therefore, has substantial power on organizational culture and, in addition to organizational behavior."

Research also points that the prevailing ethical norms in companies develop from the national cultural values and customs (Ferell and Gresham, 1985; Hunt and Vitell, 1986). Cultural background of the employees also influences the perception of EC (Herndon et al., 2001). Bourne \& Snead (1999) found that existence of community based micro culture potentially moderates an organization's ability to create homogeneous organizational ethical culture. Pointing towards the sociocultural environment of the organization, Victor and Cullen (1998) characterized it as having an inbuilt characteristic building the ethical climate of an organization. In a cross-cultural study, Chrisitie et al. (2003) demonstrated how national culture plays a significant role on the ethical reasoning and the ethical attitudes of persons, including those in the teaching profession.

\section{Conclusion}

To conclude the intention of the paper is to provide a broad overview of the impact of national culture on to the organizational culture and subsequently to the ethical climate of the organization. The work practices differ due to geographical variance and thus the organizations need to walk on a tight rope to manage balance between their own practices with that of the destination country or the country of its establishment. The ideas for this paper are drawn and derived from the published material. The issue raised are expected to sensitize and prepare the organizations to adopt the best practices prevalent in host country aligning them with their own culture thereby creating ethical climate within their organization.

\section{Conflict of Interest}

Author declares no conflict of interest with the present study

\section{References}

Adler NJ (1991) International Dimensions of Organizational Behaviour. Boston, MA: PWS-Kent. 
Arora D (2005) Foreign Multinationals in India: Adapting to India's Work Culture and Management Practices. München: Hampp ISBN 978-3-87988-969-3. - 2005, p. 149-179

Bourne S and Snead JD (1999) Environmental determinants of organizational ethical climate: A community perspective. Journal of Business Ethics 21(4): 283-290.

Briggs E, Jaramillo F and Weeks WA (2012) The influences of ethical climate and organization identity comparisons on salespeople and their job performance J. Pers. Sell. Sales Management. 32: 421-436.

Ceschi A, Sartori R, Dickert S, Costantini A (2016) Grit or honesty-humility? New insights into the moderating role of personality between the health impairment process and counterproductive work behavior Front. Psychol. 7: 1799.

Christie PMJ, Kwon IWG, Stoeberl PA, and Baumhart R (2003) A cross-cultural comparison of ethical attitudes of business managers: India Korea and the United States. Journal of Business Ethics 46: 263-287.

Deal TE and Kennedy AA (1982) Corporate Cultures: The Rites and Rituals of Corporate Life Addison Wesley Publishing Company, Reading, 126

DeConinck JB (2011) The effects of ethical climate on organizational identification, supervisory trust, and turnover among salespeople. Journal of Business Research 64: 617-624.

Dennis N and Macaulay M (2007) "Miles ahead"-using jazz to investigate improvisation and market orientation European. Journal of Marketing 41: 608-623

Ehrhart MG and Raver JL(2014) The effects of organizational climate and culture on productive and counterproductive behavior in The Handbook of Organizational Climate and Culture: Antecedents, Consequences, and Practice. eds Schneider B., Barbera K. New York, NY: Oxford University Press

Ellemer N, Pagliaro S, and Barreto, M (2013) Morality and behavioural regulation in groups: a social identity approach. Eur. Rev. Soc. Psychol. 2: 160-193.

Ferrell OC and Gresham LG (1985) A contingency framework for understanding ethical decision making in marketing. Journal of Marketing, 49(3): 87-96.

Fitzsimmons SR and Stamper CL (2014) How societal culture influences friction in the employee-organization relationship. Hum. Resource. Management. Rev. 24(1): 80-94.

Gerhart B (2009) How much does national culture constrain organizational culture? Management and Organization Review, 5: 241-259.

Goldman A, and Tabak, N (2010) Perception of ethical climate and its relationship to nurses' demographic characteristics and job satisfaction. Nursing Ethics, 17: 233-246.

Griffith R, Huergo E, Mairesse J, Peters B (2006) Innovation and productivity across four European countries. Oxford review of economic policy 22: 483-498.
Herndon NC, Fraedrich JP and Yeh QJ (2001) An investigation of moral values and the ethical content of the corporate culture: Taiwanese versus US sales people. Journal of Business Ethics 30(1): 73-85.

Hofstede (1980) Culture's Consequences: International Differences in Work-related Values. Sage Publications, Newbury Park.

Hofstede G (1983) Dimensions of National Cultures in Fifty Countries and Three Regions, In: Deregowski, Dziurawiec and Annis (eds.), Expiscations in Cross-cultural Psychology, pp. 335-355.

Hofstede G (1991) Cultures and Organizations: Software of the Mind. London: McGraw-Hill

Hofstede G (2001) Culture's Consequences: Comparing Values, Behaviors, Institutions, and Organizations Across Nations, 2nd ed. Sage Thousand Oaks, CA.

Hofstede G, Hosfstede GJ and Minkov M 2010 Cultures and Organizations: Software of the Mind. New York: McGraw-Hill.

Hunt SD and Vitell SA (1986) General Theory of Marketing Ethics. Journal of Macro marketing 6(1): 5-16.

Kim YH and Short JR (2008) Cities and economies. Routledge.

Klimas P (2016) Organizational culture and coopetition: An exploratory study of the features, models and role in the Polish Aviation Industry. Industrial Marketing Management, 53, 91-102.

Kluckhohn C (1954) Culture and behavior In G. Lindzey (Ed.): Handbook of Social psychology. (Vol. 2, pp. 921-976). Cambridge, MA: Addison-Wesley

Leung K (2008) Matching ethical work climate to in-role and extra-role behaviors in a collectivist work settingJ. Bus. Ethics 79:43-55.

Lewin K (1951) Field Theory in Social Science. New York: Harper

Lu VN, Plewa C and Ho J (2016) Managing governmental business relationships: the impact of organizational culture difference and compatibility. Australian Marketing Journal 24:93-100

Lustig MW and Koester J (1999) Intercultural Competence: Interpersonal Communication across Culture. New York: Longman.

Mayer D M (2014) A review of the literature on ethical climate and culture. In: Schneider B and Barbera K (Eds) The Handbook of Organizational Climate and Culture: Antecedents, Consequences, and Practice. New York, NY: Oxford University Press, pages 415-440

Minkov M, and Hofstede G (2012) Is national culture a meaningful concept? Cultural values delineate homogeneous national clusters of in-country regions. Cross-Cultural Research 46(2): 133-159.

Moran ET and Volkwein JF (1992) The cultural approach to the formation of organizational climate. Human relations, 45(1):19-47. 
Mulki JP, Jaramillo F and Locander WB (2006) Effects of ethical climate and supervisory trust on salesperson's job attitudes and intentions to quit. J Pers Sell Sales Manag 24: 19-26.

Murphy PE (2002) Marketing ethics at the millennium: Review, reflections, and recommendations. The Blackwell guide to business ethics, 165-185.

Nazarian A, Atkinson P and Foroudi P (2017) Influence of national culture and balanced organizational culture on the hotel industry's performance. International Journal of Hospitality Management 63: 22-32.

Nelson RE and Gopalan S(2003) Do Organizational Cultures Replicate National Cultures? Isomorphism, Rejection and Reciprocal Opposition in the Corporate Values of Three Countries. Organization Studies 24(7): 1115-1151.

Newman A, Round H, Bhattacharya S, and Roy A (2017) Ethical climates in organizations: a review and research agenda. Bus Ethic Q 27: 475-512.

Nikčević G (2014) The influence of national culture on certain types of organizational culture. FACTA UNIVERSITATISEconomics and Organization 11(2): 149-162.

Olson L (1998) Hospital nurses' perceptions of the ethical climate of their work setting. J Nurs Scholarsh 30: 345-349. DOI: https://doi.org/10.1111/j.1547-5069.1998.tb01331.x

Pagliaro S, Lo Presti A, Barattucci M, Giannella VA and Barreto $M$ (2018) On the effects of ethical climate(s) on employees' behaviour: a social identity approach. Front. Psychol 9: 960

Parboteeah KP, Cullen JB, Victor B, and Sakano T (2005) National culture and ethical climates: A comparison of US and Japanese accounting firms. MIR: Management International Review 459-481.

Peterson DK (2002) Deviant workplace behavior and the organization's ethical climate. J. Bus. Psychol. 17 47-61

SatheV (1985) Culture and Related Corporate Realities Homewood, IL: Richard D. Irwin
Schein EH (1999) Empowerment, coercive, persuasion and organizational learning: do they connect? The Learning Organization 6(4): 163-172.

Scherer AG, Palazzo G and Baumann D (2006) Global rules and private actors. Towards a new role of the TNC in global governance. Business Ethics Quarterly: 502-532

Schminke M, Arnaud A and Kuenzi M (2007) The power of ethical work climates. Organizational Dynamics 36(2): 171-186.

Shweder RA, Le Vine RA, LeVine RA and Economiste RAL (1984) Culture theory: Essays on mind, self and emotion. Cambridge University Press.

Simha A and Cullen JB (2012) Ethical climates and their effects on organizational outcomes: Implications from the past and prophecies for the future. Academy of management perspectives 26: $20-34$.

Soeters J and Schreuder (1988) The interaction between national and organizational culture in accounting firms. Accounting, Organizations and Society 13(1): 75-85

Taylor S \& Osland J (2012) Introduction to HRM's role in sustainability: Systems, strategies, and practices. Human Resource Management. 51(6): 789-798.

Trevino LK (1990) A Cultural Perspective on Changing and Developing Organizational Ethics. Research in Organizational Change and Development 4:195 -223.

Unal OF (2012) Relationship between organizational commitment and ethical climate: The mediating role of job satisfaction dimensions (a study in a group of companies in Turkey). Journal of WEI Business and Economics 1(1): 92-105.

Victor B and Cullen JB (1988) The Organizational Bases of Ethical Work Climates Administrative Science Quarterly 33(1): 101-125. https://doi.org/10.2307/2392857 